\title{
TRIBUNALES SUPERIORES DE JUSTICIA Y LÍMITES AL PRONUNCIAMIENTO DE SENTENCIAS CONDENATORIAS DE REEMPLAZO
}

En razón del recurso de nulidad, el artículo 385 del Código Procesal Penal confiere a las cortes del país poder para invalidar una sentencia penal viciada y también para reemplazarla discrecionalmente en los supuestos previstos por la norma. El artículo 360 del mismo texto legal, en cambio, parece proscribir el ejercicio oficial de esa potestad jurisdiccional, al establecer que en materia de recursos está vedado al Tribunal de Nulidad extender el efecto de su decisión a cuestiones no planteadas por el recurrente o más allá de los límites de lo solicitado. A partir de un caso en el que la Corte de Apelaciones de Puerto Montt acogió un recurso de nulidad de la defensa y sin petición del recurrente, ni previo debate de partes, dictó una nueva sentencia de reemplazo que causó agravio al condenado, proponemos una interpretación de ambas disposiciones que persigue armonizar su aplicación de un modo coherente con el respeto al debido proceso.

Germán Echeverría Ramirez*

1. Los límites de la sentencia de reemplazo consagrados en el artículo 385 del Código Procesal Penal: 1.a. La sentencia de reemplazo sólo puede ser solicitada por el condenado; 1.b. El condenado que recurre de nulidad zestá obligado a pedir sentencia de reemplazo en los casos previstos en el artículo 385 o puede en esos casos pedir igualmente la sentencia de reenvío y la realización de un nuevo juicio oral?; 1.c. Peticiones del recurrente como límite a la dictación de la sentencia de reemplazo; 1.d. Control vertical v/s control horizontal de la sentencia; 1.e. Veto a la iniciativa del tribunal; 2. Un sistema de control que no perjudique al recurrente: 2.a. La capacidad del tribunal está determinada por la competencia específica conferida por las partes; 3. Un caso de sentencia de reemplazo sorpresiva y que causó agravio al condenado: 3.a. Una victoria pirrica; 3.b. Fundamentos de la acción de amparo constitucional; 3.c. La sentencia de reemplazo como prerrogativa absoluta de las cortes; 4. Sentencia de reemplazo: facultad legal de oficio y garantias fundamentales: 4.a. La interpretación a favor de la economía procesal; 4.b. Eficiencia no es sólo celeridad y ahorro de recursos, sino también oportunidad de defenderse; 4.c. Acogida la nulidad, ¿sus efectos están determinados por la ley y no por el petitorio de partes?; 4.d. Iura novit curia y contradictorio como presupuesto de validez del fallo; 4.e. La forma de cumplimiento de la pena debe ser debatida por la defensa, porque integra la sentencia definitiva; 4.f. La defensa tiene derecho a expresarse basta la completa ejecución del fallo; Bibliografia.

Poco se ha reflexionado y menos se ha escrito sobre los límites que un sistema procesal penal de inspiración acusatoria, como el vigente en nuestro país, debe imponer al pronunciamiento de sentencias de reemplazo emanadas de los Tribunales Superiores de Justicia.

\footnotetext{
${ }^{1}$ Este trabajo corresponde al cumplimiento de una de las metas de desempeño colectivo año 2010 de la Defensoría Regional de Los Lagos y recoge parte del trabajo de apoyo a las funciones de defensa penal pública realizado por su Unidad de Estudios Regional.

* Profesional de la Unidad de Estudios de la Defensoría Regional de Los Lagos. Abogado y Periodista, Universidad de Chile; email: gecheverria@dpp.cl
} 
Echeverría - Límites a la dictación de sentencias penales de reemplazo...

De acuerdo con lo dispuesto en el artículo 385 del Código Procesal Penal, las Cortes de Apelaciones y la Excma. Corte Suprema, en su caso, están autorizadas para invalidar sólo la sentencia y sin nuevo juicio, pero separadamente, dictar el pronunciamiento de reemplazo que se conforme a la ley, si la causal de nulidad acogida no se refiere a las formalidades del juicio ni a los hechos y circunstancias que se dieron por probados, sino que, por el contrario, obedece a que el fallo calificó de delito un hecho que la ley no tipifica como tal, impuso una pena cuando no procedía hacerlo o aplicó una superior a la que legalmente correspondía.

Si bien el Tribunal de Nulidad tiene competencia para emitir un pronunciamiento de evidente efecto negativo, al excluir del ordenamiento jurídico el fallo invalidado puede también inmediatamente fallar el fondo del asunto a través del pronunciamiento positivo de una nueva sentencia, denominada de reemplazo, inimpugnable a través de los recursos procesales ordinarios y extraordinarios ${ }^{2}$, según lo ha declarado la opinión mayoritaria de los integrantes de la sala penal de la Excma. Corte Suprema. ${ }^{3}$

\footnotetext{
2 Artículo 387 del Código Procesal Penal: La resolución que fallare un recurso de nulidad no será susceptible de recurso alguno, sin perjuicio de la revisión de la sentencia condenatoria firme de que se trata en este Código.

Tampoco será susceptible de recurso alguno la sentencia que se dictare en el nuevo juicio que se realizare como consecuencia de la resolución que hubiere acogido el recurso de nulidad. No obstante, si la sentencia fuere condenatoria y la que se hubiere anulado hubiese sido absolutoria, procederá el recurso de nulidad a favor del acusado, conforme a las reglas generales.

${ }^{3}$ Por ejemplo, en la causa Rol Excma. Corte Suprema No 4370-08, de 19 de agosto de 2008, el máximo tribunal del país dijo: "Que de conformidad a lo dispuesto en el artículo 387 del Código Procesal Penal, la resolución que falle un recurso de nulidad, no será susceptible de recurso alguno. Y visto además, lo dispuesto en los artículos 545 y 549 del Código Orgánico de Tribunales, se declara inadmisible el recurso de queja interpuesto en lo principal de fojas 4. Acordada con el voto en contra de los Ministros señores Rodríguez y Dolmestch, quienes estuvieron por acogerlo a tramitación, por cuanto si bien el artículo 387 del Código Procesal Penal dispone que no procede recurso alguno en contra de las resoluciones que fallan los recursos de nulidad, es lo cierto que el artículo 63, $\mathrm{N}^{\circ} 1^{\circ}$, letra b), del Código Orgánico de Tribunales les asigna expresamente la calidad de única instancia, amén que configura exactamente una de las causales que autorizan el recurso de queja, en los términos prescritos en el inciso primero del artículo 545 del mismo cuerpo legal, de modo que su aplicación se torna preferente por tratarse de una norma especial propia, sin perjuicio que, a mayor abundamiento, el artículo $8^{\circ}, \mathrm{N}^{\circ} 2^{\circ}$, letra h), del Pacto de San José de Costa Rica, suscrito por Chile, considera los recursos ante el superior jerárquico de las resoluciones agraviantes en materia penal, con mayor propiedad aún si se denuncian faltas o abusos graves y no obstante que este derecho no se contempla en nuestra Carta Fundamental, resulta igualmente obligatorio, en razón a que los pactos internacionales ratificados por nuestro país, y en actual vigencia ostentan un rango superior al de una ley, en virtud de lo prevenido en el artículo $5^{\circ}$ de la Constitución Política de la Republica, cuando como el precitado, se refieren a los derechos esenciales que emanan de la naturaleza humana. Rol No 4370-08 Pronunciado por la Segunda Sala integrada por los Ministros Sres. Nibaldo Segura P., Jaime Rodríguez E., Rubén Ballesteros C., Hugo Dolmestch U. y Carlos Künsemüller L. Autorizada por la Secretaria Subrogante de esta Corte Suprema doña Carola Herrera Brummer".
} 
En ese sentido, la facultad otorgada por el legislador al tribunal de nulidad ya no sólo para invalidar una sentencia, sino también para decidir perentoriamente la litis, trae a presencia las reminiscencias del viejo recurso de casación regulado en el derogado Código de Procedimiento Penal de 1906. Dicho medio de impugnación, a menudo invocado por los operadores de la justicia criminal de antaño, reconocía al superior jerárquico no sólo el poder de corregir los errores in iudicando, sino también el de expresar la verdad decisoria del caso, a pesar de no haber presenciado la producción de la prueba, ni asistido a los actos de juzgamiento del acusado.

Si bien la doctrina admite que el recurso de nulidad presenta ciertos rasgos de semejanza con el extinto recurso de casación penal ${ }^{4}$, las diferencias anotadas entre ambos remedios no hacen más que reflejar las agudas diferencias entre el antiguo juzgamiento de inspiración inquisitiva y el actual modo de decidir el conflicto bajo formas propias de un modelo de fuerte orientación acusatoria, como el vigente hoy en el país.

Antes de precisar la principal diferencia entre ambos recursos, parece oportuno recordar que la sustitución del modelo de juzgamiento inquisitivo por otro de orientación acusatoria significó una profunda redistribución de los poderes de persecución penal y, por ello, de las funciones asociadas a su ejercicio, también en el ámbito de la impugnación de las resoluciones judiciales. Entre otras, implicó una triple separación de las funciones de investigación, acusación y enjuiciamiento. ${ }^{5}$

Horvitz y López sostienen que el principio acusatorio está en íntima relación con numerosas garantías procesales, tales como la imparcialidad del tribunal; la defensa del imputado; la contradicción entre partes como presupuesto de validez de la decisión; la correlación entre imputación y fallo; además de la prohibición de reforma en perjuicio, entre muchas otras, que constituyen derivaciones del mismo principio ${ }^{6}$. Ellas, a nuestro juicio, deben reflejarse y

\footnotetext{
${ }^{4}$ Marín G., J.: "El recurso de nulidad en el Código Procesal Penal: el reenvío y la sentencia de reemplazo", en Informes en Derecho N 6, noviembre 2009, Ed. Centro de Documentación de la Defensoría Penal Pública, p. 30, donde en apoyo de esta conclusión cita a Cortez M., Gonzalo: El recurso de nulidad, Lexis Nexis, 2006, p. 34. Véase también Tavolari: Instituciones del nuevo proceso penal, Editorial Jurídica de Chile, 2005, p. 105. Riego y Duce observan: "Este recurso se construye en lo fundamental sobre la misma base del recurso de casación, es decir, se trata de un recurso que busca anular el juicio y/o la sentencia, invocando una violación del derecho aplicable al caso". Riego y Duce: Proceso penal, Jurídica de Chile, 2007, p. 515.

${ }^{5}$ Horvitz Lennon, M. y López Masle, J.: Derecho Procesal Penal Chileno, Tomo I, Editorial Jurídica de Chile, Santiago, 2002, p. 43.

${ }^{6}$ Ibid. p. 46.
} 
Echeverría - Límites a la dictación de sentencias penales de reemplazo...

expresarse durante todo el procedimiento, incluida la fase de impugnación y revisión de la sentencia.?

De lo contrario, muchas de estas garantías inherentes al actual juzgamiento de inspiración acusatoria serían, hoy, sólo una quimera bajo un esquema de escrutinio simplemente jerárquico de los pronunciamientos judiciales, como el contemplado en el derogado recurso de casación penal.

Lo explica con nitidez Juan Carlos Marín al sostener que la típica facultad de la corte para dictar sentencias de reemplazo en virtud de haberse acogido un recurso de casación es absolutamente excepcional tratándose del recurso de nulidad, que no tiene, por regla general, dentro de sus características esta función positiva. $^{8}$

Esta fuerte restricción al recurso de nulidad impuesta por el modelo de inspiración acusatoria que informa a la ley procesal penal aparece justificada en palabras de Juan Carlos Marín, en primer término, porque en el nuevo proceso penal la clave está en el juicio oral. "Allí debe rendirse y apreciarse la prueba que servirá para condenar o absolver al imputado. No es razonable, en este sistema, que el tribunal ad quem dicte continuamente sentencias de reemplazo porque se estaría resolviendo el fondo sin haber presenciado directamente la prueba", afirma este autor.

En tal sentido, es oportuno recordar que por esas mismas razones de respeto al modelo acusatorio se desestimó en su oportunidad la incorporación del llamado recurso extraordinario que fuera promovido por la Cámara de Diputados.

Durante su primer trámite legislativo, este medio de impugnación fue adicionado al proyecto de Código Procesal Penal, con el propósito de permitir el examen judicial de las sentencias que se hubieran apartado manifiesta y arbitrariamente de la prueba rendida, pero el Senado lo suprimió definitivamente con miras a resguardar la centralidad del juicio oral y las potestades de los jueces que en audiencia conocieron directamente, sin intermediaciones, la prueba producida.

Sobre este punto, la entonces ministra de Justicia, Soledad Alvear, sostuvo que el recurso extraordinario hace perder centralidad al juicio oral como instancia

\footnotetext{
${ }^{7}$ El artículo 7 del Código Procesal Penal establece que las facultades, derechos y garantías que la Constitución Política de la República, este código y otras leyes reconocen al imputado, podrán hacerse valer por la persona a quien se atribuyere participación en un hecho punible desde la primera actuación del procedimiento dirigido en su contra y hasta la completa ejecución de la sentencia.

8 Marín G., J. "El recurso de nulidad..." (nota 4), p. 33.
} 
fundamental del sistema acusatorio... " En efecto, en un juicio oral, en el cual rige como principio fundamental la inmediación, esto es, que la convicción se adquiere a partir de los sucesos y el contexto de la audiencia de juicio oral y no de la lectura de los expedientes, no se entiende de qué manera el Tribunal que ha de conocer el recurso pudiera estar en mejores condiciones que el Tribunal de Juicio Oral para evitar que se produzca un apartamiento manifiesto y arbitrario de la prueba rendida durante el juicio oral"10, afirmaron en su minuto los profesores María Inés Horvitz y Jorge Bofill.

Esta decisión legislativa de rechazo al recurso extraordinario, fue coherente con el Mensaje bajo el cual el Presidente de la República, Eduardo Frei Ruiz-Tagle, a mediados de los años 90, sometió a la consideración del Congreso la aprobación de un nuevo Código Procesal Penal. La supresión de la lógica inquisitiva en el modelo propuesto para abordar el control e impugnación de las sentencias definitivas quedó expresada del siguiente modo:

"La concepción básica que inspira el régimen de recursos que el proyecto propone implica un radical cambio en el sistema de controles de la actividad de los jueces penales. El modelo vigente (Código de Procedimiento Penal de 1906) funciona sobre la base de un muy intenso sistema de controles verticales. Se puede decir que todas las decisiones de relevancia que un juez del crimen adopta son objeto de revisión, incluso sin reclamación de parte, por sus superiores jerárquicos. Este sistema, que se explica históricamente por la necesidad de controlar a un órgano único en primera instancia, con exceso de atribuciones, ha contribuido con fuerza a la irracionalidad administrativa del sistema, a la desvalorización de las decisiones del juez individual y a las ya mencionadas burocratización y pérdida de individualidad de la función judicial y su proyección pública". ${ }^{11}$

"Como se ha expuesto en las explicaciones anteriores, el sistema propuesto plantea un conjunto mucho más complejo de órganos y de relaciones entre ellos en el nivel de la instancia general. A partir de ese diseño, el sistema de controles de la actuación de cada uno de los funcionarios públicos que intervienen está dado por la intervención de los otros en las distintas etapas del procedimiento. Éstas han sido diseñadas con el objetivo de evitar la concentración de facultades y lograr que cada una de las decisiones de relevancia sea objeto de consideración por más de uno de los órganos del

\footnotetext{
${ }_{9}^{9}$ Maturana M., Cristián (Coord.), Reforma procesal penal, génesis, historia sistematizada y concordancias, t. III, Ed. Jurídica de Chile, Santiago, 2003, p. 83.

${ }^{10}$ Ibid. p. 85.

${ }^{11}$ Código Procesal Penal: Mensaje, quinta edición especial para estudiantes, Editorial Jurídica de Chile, Santiago, 2008, p. 24.
} 
Echeverría - Límites a la dictación de sentencias penales de reemplazo...

sistema, así como de un debate previo con la mayor transparencia posible". ${ }^{12}$

Así las cosas, la facultad del Tribunal de Nulidad para dictar sentencias de reemplazo debe armonizarse con los actuales valores del sistema de juzgamiento penal, a efectos de evitar el ejercicio de ese poder de control bajo modalidades de absolutismo jerárquico al interior del aparato judicial, capaces de amenazar garantías esenciales del actual proceso penal, tales como el derecho al juicio oral y a la actuación de la defensa material y técnica.

De hecho, existe una norma destinada precisamente a cautelar el conocimiento y decisión de los recursos procesales bajo una estricta lógica acusatoria, que expresamente prohíbe al tribunal ad quem fallar los recursos procesales al margen de las alegaciones expuestas por las partes y en perjuicio del recurrente, como la establecida en el artículo 360 del Código Procesal Penal.

\section{Los límites de la sentencia de reemplazo consagrados en el artículo 385 del Código Procesal Penal}

El artículo 385 del Código Procesal Penal establece que la corte podrá invalidar sólo la sentencia y dictar, sin nueva audiencia pero separadamente, la sentencia de reemplazo que se conformare a la ley, si la causal de nulidad no se refiriere a las formalidades del juicio ni a los hechos y circunstancias que se hubieren dado por probados, sino que se debiere a que el fallo hubiere calificado de delito un hecho que la ley no considerare tal, aplicado una pena cuando no procediere aplicar pena alguna, o impuesto una superior a la que legalmente correspondiere.

Juan Carlos Marín afirma que la primera restricción de este precepto, relativa a las formalidades del juicio, parece referirse a la prohibición de dictar una sentencia de reemplazo cuando concurran los motivos absolutos de nulidad del artículo 374 del Código Procesal Penal o, en todo caso, los denominados vicios in procedendo ${ }^{13} \ldots$. Cuando se esté frente a violaciones de normas procesales el tribunal que anula la sentencia debe, además, anular el juicio y remitir los antecedentes al

\footnotetext{
12 Ibid.

${ }^{13}$ Juan Carlos Marín cita a Piero Calamandrei, quien en relación con este tipo de vicios comenta: "Ahora bien, así como las normas de derecho procesal, al contrario de las de derecho sustancial, se han establecido por el legislador en previsión del proceso, y, por tanto, (...) se dirigen directamente también al juez para regular su conducta en el proceso, puede ocurrir que, cuando se verifique en el proceso el hecho específico que una norma de derecho procesal supone, nazca una voluntad concreta de la ley de la que el único destinatario sea el juez, un mandato dirigido singularmente al juez al objeto de regular en cierto modo, positivo o negativo, su conducta; en este caso, si el juez no se ajusta al inmediato mandato que la ley le dirige, si obra de un modo diverso del que le impone la voluntad de la ley (...) comete la violación de ley que típicamente se llama error in procedendo" Piero Calamandrei, "La distinción en error in iudicando y error in procedendo", en Estudios sobre el proceso civil, trad. Santiago Sentís Melendo, Bibliográfica Argentina, Buenos Aires, 1945, pág. 167.
} 
tribunal no inhabilitado. No existe posibilidad, en este evento, para que la corte de inmediato dicte una nueva sentencia. ${ }^{14}$

Horvitz y López advierten que para que opere la hipótesis descrita en el artículo 385 del Código Procesal Penal no sólo se requiere que el error pueda ser enmendado directamente por la corte sin necesidad de una nueva vista, sino que se requiere también que se trate de un recurso de nulidad interpuesto a favor del imputado, porque lo que se permite enmendar directamente es, en las tres hipótesis mencionadas, una sentencia de carácter condenatorio. ${ }^{15}$

\section{1.a. La sentencia de reemplazo sólo puede ser solicitada por el condenado}

Aparece proscrita, entonces, la posibilidad de que el fiscal del Ministerio Público, el querellante o la víctima, incluso, de conformidad con lo previsto en el artículo 109 f) del Código Procesal Penal ${ }^{16}$ puedan pedir al Tribunal de Nulidad que se invalide la sentencia definitiva y, sin nuevo juicio, se condene al acusado, por descansar la decisión recurrida en un error de derecho que significó calificar como atípica una conducta penada por la ley o por haber impuesto una pena menor a la que legalmente correspondía o no aplicar pena alguna cuando el ordenamiento jurídico mandaba hacerlo.

En esos casos, como es evidente, la petición del recurrente no puede reclamar la dictación de una sentencia de reemplazo y, en cambio, debe limitarse a solicitar de la respectiva corte que, de conformidad con lo dispuesto en el artículo 386 del Código Procesal Penal, junto con la invalidación de la sentencia, determine el estado en que ha de quedar el procedimiento, para que un tribunal no inhabilitado disponga la realización de un nuevo juicio oral.

Lo anterior no es más que expresión de lo dispuesto en el artículo $1^{\circ}$ del Código Procesal Penal. ${ }^{17}$ Horvitz y López sostienen que lo que la ley desea es que la sentencia condenatoria sea siempre la consecuencia de la convicción directamente obtenida por el tribunal, con respeto a los principios de publicidad, oralidad e inmediación, lo que se vería afectado si, tras una sentencia absolutoria,

\footnotetext{
${ }^{14}$ Marín G., J.: "El recurso..." (nota 4), p. 52.

${ }^{15}$ Horvitz Lennon, M y López Masle, J.: Derecho Procesal... (nota 5), p. 444.

${ }^{16}$ Artículo 109 f) del Código Procesal Penal. Derechos de la víctima. La víctima podrá intervenir en el procedimiento penal conforme a lo establecido en este código, y tendrá, entre otros, los siguientes derechos: "f) Impugnar el sobreseimiento temporal o definitivo o la sentencia absolutoria, aun cuando no hubiere intervenido en el procedimiento".

17 Artículo $1^{\circ}$ del Código Procesal Penal. Juicio previo y única persecución. Ninguna persona podrá ser condenada o penada, ni sometida a una de las medidas de seguridad establecidas en este código, sino en virtud de una sentencia fundada, dictada por un tribunal imparcial. Toda persona tiene derecho a un juicio previo, oral y público, desarrollado en conformidad con las normas de este cuerpo legal.
} 
Echeverría - Límites a la dictación de sentencias penales de reemplazo...

se permitiera al Tribunal de Nulidad dictar directamente una sentencia de reemplazo de contenido condenatorio. ${ }^{18}$

Lo confirma la discusión legislativa que dio origen a la reforma de la ley 20.074, oportunidad en la que el representante del Ministerio Público planteó la posibilidad de ampliar los casos en que procedía la sentencia de reemplazo. Tal como lo expone Cortez Matcovich, la modificación propuesta apuntaba al supuesto en que se acogiera un recurso de nulidad en el caso que la sentencia adjudicara una pena inferior a la que legalmente correspondía. ${ }^{19}$

Frente a las escasas situaciones en que está prevista la sentencia de reemplazo, todas ellas en beneficio del imputado, el Fiscal Nacional planteó que "el Ministerio Público está en una desigualdad absoluta frente a la ley, porque, por ejemplo, si se aplicó una pena ínfima en relación con lo que realmente debía haberse impuesto y el fiscal quiere recurrir de nulidad, si la corte le encuentra la razón anula el juicio completo y hay que partir de cero, lo que desincentiva a la fiscalía para recurrir de nulidad aunque tenga la razón por el riesgo de tener que ir por segunda vez a un juicio oral". ${ }^{20}$

Ante esta reflexión crítica, el profesor Raúl Tavolari sostuvo que, en el nuevo sistema, la filosofía es que así como excepcionalmente se permite el ejercicio del recurso de apelación, por regla general, tampoco procede sentencia de reemplazo en el caso de la nulidad, salvo cuando vaya a favor del imputado. ${ }^{21}$

Discreparon de lo anterior, el senador Espina y el entonces senador Viera Gallo, quienes afirmaron que a la ciudadanía no le parece, en casos de grave connotación pública, que anulado el juicio por solicitar mayor pena deba realizarse todo el proceso oral de nuevo, y agregaron que deberían estudiarse las hipótesis en las cuales procedería la sentencia de reemplazo y en qué otras situaciones se mantiene la norma actual. ${ }^{22}$

Cortez Matcovich escribe que en este debate los representantes del Gobierno explicaron que la dictación de una sentencia de reemplazo en el modelo acusatorio es una excepción absoluta; no debería existir sentencia de reemplazo y deberíamos escandalizarnos, pues en estos casos siempre debería anularse todo el juicio, porque el juicio oral es una cosa sacrosanta (...). Se abrió la posibilidad de la sentencia de reemplazo a favor del imputado sólo porque tratándose de una sentencia que le favorece, parecía excesivo que debiera rehacerse el juicio oral. Por

\footnotetext{
${ }^{18}$ Horvitz Lennon, M y López Masle, J.: Derecho Procesal... (nota 5), p. 444.

${ }^{19}$ Cortez Matcovich, G.: El recurso de nulidad, doctrina y jurisprudencia, Editorial Lexis Nexis, Santiago, 2006, p. 404.

${ }^{20}$ Cortez Matcovich, G.: El recurso de nulidad... (nota 19), p. 404.

${ }^{21}$ Segundo Informe de la Comisión de Constitución, Legislación, Justicia y Reglamento del Senado, de 25 de agosto de 2005 citado por Cortez Matcovich, G.: El recurso de nulidad... (nota 19), p. 404. 22 Ibid.
} 
ello el principio de la nulidad total sólo cedió en beneficio del imputado... ${ }^{23} \mathrm{Y}$ esta situación se mantiene inalterada hasta el día de hoy.

\section{1.b. El condenado que recurre de nulidad ¿está obligado a pedir sentencia de reemplazo en los casos previstos en el artículo 385 o puede en esos casos pedir igualmente la sentencia de reenvío y la realización de un nuevo juicio oral?}

Como se advierte de la lectura del artículo 385 del Código Procesal Penal, tres son las situaciones que autorizarían al recurrente condenado a solicitar sentencia de reemplazo:

-La sentencia anulada hubiere calificado de delito un hecho que la ley no considerare tal.

-La sentencia anulada hubiere aplicado una pena cuando no procediere aplicar pena alguna.

-La sentencia anulada hubiere impuesto una superior a la que legalmente correspondiere.

La pregunta que surge es si en estos casos, que autorizan al recurrente a pedir sentencia de reemplazo, puede, sin embargo, el condenado renunciar a ese derecho y solicitar a la corte que dicte la correspondiente sentencia de reenvío y determine el estado en que hubiere de quedar el procedimiento, ordenando la remisión de los antecedentes al tribunal no inhabilitado que corresponda para que éste disponga la realización de un nuevo juicio oral.

El tema no es baladí. Estamos decididamente persuadidos de que la competencia específica del Tribunal de Nulidad está determinada por las peticiones de las partes, tal como expresamente lo reconoce el artículo 360 del Código Procesal Penal ${ }^{24}$ en perfecta coherencia con la lógica adversarial y acusatoria plasmada en el actual sistema de juzgamiento criminal.

$\mathrm{Y}$ en ese sentido, nos inclinamos por sostener que el derecho al juicio oral es una garantía inalienable del imputado, que frente a la invalidación de la sentencia puede pedir la realización de un nuevo juicio oral, aun cuando el vicio se haya cometido en su pronunciamiento, como de hecho ocurre en los casos en que se permite a la corte dictar una sentencia de reemplazo.

En efecto, el inciso $2^{\circ}$ del artículo 386 del Código Procesal Penal dispone expresamente que no es obstáculo para que se ordene efectuar un nuevo juicio oral

\footnotetext{
${ }^{23}$ Cortez Matcovich, G.: El recurso de nulidad... (nota 19), p. 405.

24 Artículo 360 del Código Procesal Penal. Decisiones sobre los recursos. El tribunal que conociere de un recurso sólo podrá pronunciarse sobre las solicitudes formuladas por los recurrentes, quedándole vedado extender el efecto de su decisión a cuestiones no planteadas por ellos o más allá de los límites de lo solicitado...
} 
Echeverría - Límites a la dictación de sentencias penales de reemplazo...

la circunstancia de haberse dado lugar al recurso por un vicio o defecto cometido en el pronunciamiento mismo de la sentencia.

Y a mayor abundamiento, el legislador en el artículo 385 tampoco ordenó en forma imperativa dictar sentencia de reemplazo en los casos que indica, desde que expresamente reconoció que la corte podrá invalidar sólo la sentencia y dictar, sin nueva audiencia pero separadamente, la sentencia de reemplazo que se conformare a la ley, en las hipótesis de condenas ya estudiadas, de lo que se desprende también la posibilidad de dictar una sentencia de reenvío.

\section{1.c. Peticiones del recurrente como límite a la dictación de la sentencia de reemplazo}

Si al condenado, en nuestra legislación, se le reconoce un derecho de opción, en el sentido de autorizarlo a pedir del Tribunal de Nulidad o la sentencia de reenvío o una de reemplazo cuando la causal de nulidad no se refiriere a las formalidades del juicio ni a los hechos y circunstancias que se hubieren dado por probados en los términos expuestos por el artículo 385 del Código Procesal Penal, la pregunta es evidente: ¿qué papel juega, entonces, la petición concreta del recurrente en el ejercicio de la facultad reconocida al Tribunal de Nulidad para dictar una sentencia de reemplazo al margen de un nuevo juicio?

La interrogante planteada se responde desde la perspectiva del cambio radical que el actual Código Procesal Penal introdujo al sistema de recursos y a los controles sobre la actividad jurisdiccional.

Desde luego las peticiones del recurrente como límite a la actuación del tribunal deben vincularse necesariamente con la garantía reconocida en el artículo $1^{\circ}$ del Código Procesal Penal, que asegura al justiciable el derecho a una sentencia pronunciada por un juez imparcial.

Sobre esta materia el profesor Andrés Bordalí plantea que la imparcialidad del tribunal en el actual proceso penal no sólo aparece cautelada por la distribución de las funciones de investigar, acusar, defender y juzgar en diferentes órganos, sino, también, en la expresa proscripción de los poderes probatorios oficiosos del juez, porque a su juicio el legislador chileno siguió la senda de un modelo de proceso penal adversarial o acusatorio puro, donde el poder de probar sólo corresponde a las partes. ${ }^{25}$ (...) "La función de justicia en el sentido de hacer aplicar la ley ya estaría asignada en parte al órgano persecutor estatal. Por otra parte, un respeto irrestricto del principio de presunción de inocencia también parecería aconsejar no darle estos poderes probatorios oficiosos al tribunal, pues

\footnotetext{
25 Bordalí Salamanca, A.: "El derecho fundamental a un tribunal independiente e imparcial en el ordenamiento jurídico chileno", en Revista de Derecho de la Pontificia Universidad Católica de Valparaíso XXXIII, Valparaíso, $2^{\circ}$ Semestre de 2009, p. 289.
} 
una actuación del tribunal podría perjudicar este halo protector del que están provistos todos los imputados por el delito". ${ }^{26}$

Por eso, estamos convencidos que el juzgador que se desentiende de lo alegado y pedido por las partes en el curso del actual proceso penal compromete severamente su neutralidad e indiferencia frente a los intervinientes. ${ }^{27} \mathrm{Si}$ bien no existe un juez objetivo, sin historia personal y ajeno a las influencias culturales, es posible aspirar, sin embargo, a un juzgador imparcial. Sería verdaderamente imparcial aquél que no se desvincula de lo alegado por ninguna de las partes para decidir desde una postura propia, personal y por encima del contradictorio, sino que es verdaderamente desinteresado el juez que resuelve escuchando, considerando e incorporando a su proceso deliberativo todas las posturas contrapuestas que chocan. ${ }^{28}$

Así, tal como lo escribe Cortez Matcovich, en el escenario vigente los recursos procesales dejan de estar configurados como mecanismos de control jerárquico de los errores de los tribunales inferiores y pasan a ser concebidos como medios de impugnación a solicitud de la parte agraviada ${ }^{29}$, preservando así la imparcialidad del juzgador.

\section{1.d. Control vertical v/s control horizontal de la sentencia}

En esta nueva concepción, los mecanismos de impugnación de las resoluciones judiciales se proyectan como un derecho o facultad de las partes y no como un mecanismo de control jerárquico de las decisiones de los tribunales inferiores, razón por la cual se suprimió el trámite de la consulta al superior y la reforma de la decisión en perjuicio del condenado que recurre la sentencia que le causa agravio.

Así lo entienden los abogados que formaron parte de los equipos redactores del actual Código Procesal Penal, profesores Cristián Riego y Mauricio Duce, quienes explican en los siguientes términos el llamado control horizontal instalado al interior del actual proceso penal: "De este modo los fiscales, que son quienes encarnan el poder persecutorio estatal, son controlados en su actuación fundamentalmente por los jueces y defensores, los jueces por su parte actúan limitados y controlados por las partes. El defensor es controlado por el juez, el fiscal, por su propio cliente, y finalmente todos son sometidos a un intenso control por medio de su exposición pública". ${ }^{30}$

\footnotetext{
${ }^{26}$ Ibid.

${ }^{27}$ Echeverría Ramírez, G.: "Imparcialidad del tribunal oral en lo penal: tras la conquista de la garantía", en Revista de Derecho Universidad de Austral de Chile, volumen XXIII-N¹, Valdivia, 2010, pp. 269-310.

28 Valenzuela Cori, R.: Conflicto y Humanidades. Un Ensayo sobre Argumentación Jurídica, Editorial Jurídica de Chile, Santiago, primera edición, octubre 2004, pp. 156, 157 y 158.

${ }^{29}$ Cortez Matcovich, G.: El recurso de nulidad... (nota 19), p. 29.

30 Riego, C. y Duce, M.: Proceso Penal, Editorial Jurídica, Santiago, 2007, p. 507.
} 
Echeverría - Límites a la dictación de sentencias penales de reemplazo...

No es por otra razón que el legislador expresamente reguló una verdadera parte general de los recursos procesales, precisamente para preservar también en esta etapa del procedimiento la vigencia y valores propios de un juzgamiento de inspiración acusatoria.

Y de hecho, así lo dijo expresamente el legislador al sostener que los recursos se regirán por las normas del Libro III del Código Procesal Penal, y en lo que no aparezca en ellas regulado, serán aplicables de modo supletorio las disposiciones del juicio oral ${ }^{31}$, que, como aparece de manifiesto, son las que de mejor modo resguardan el contradictorio de partes como presupuesto esencial de la decisión jurisdiccional y aseguran la pasividad del tribunal durante el debate.

Consta de la historia de la ley, que en esta materia quedó proscrita, expresamente, la posibilidad de aplicar supletoriamente las normas del procedimiento civil, porque tal como lo informó el Senado se estimó que una remisión a esas disposiciones podría entrabar el sistema de impugnación, pues son sistemas incompatibles, y porque el Código de Procedimiento Civil está enfocado hacia un procedimiento inquisitivo y escrito, razón por la cual se sugirió incorporar una regla en la parte general de los recursos que haga aplicable a éstos el debate del juicio oral. ${ }^{32}$

\section{1.e. Veto a la iniciativa del tribunal}

La Excma. Corte Suprema ha reconocido la vigencia del principio acusatorio durante la vista de los recursos procesales, al plantear que en la reforma penal las dudas del tribunal ad quem deben ser satisfechas por las partes, en el proceso, fiscal y/o querellante en su caso, y defensor. Ellos deben poner en conocimiento del tribunal todos sus argumentos y plantear los hechos de forma acabada y suficiente para que el tribunal quede bien informado sobre aquello que ha sido sometido a su conocimiento, de modo que, de subsistir cualquier duda o de haber verificado alguna inexactitud, el tribunal pregunta a las mismas partes, en la audiencia, sobre lo que le ha resultado oscuro o desconocido. ${ }^{33}$

Agregó el máximo tribunal del país que esta forma de llevar adelante la audiencia y la vista de las causas ante las cortes de apelaciones es una manifestación del principio contradictorio que rige en el nuevo sistema penal, y que constituye un elemento del derecho a defensa y, además, del debido proceso, por cuanto la imparcialidad del tribunal se asegura y garantiza a través del veto a su

\footnotetext{
31 Artículo 361. Aplicación supletoria. Los recursos se regirán por las normas de este Libro. Supletoriamente, serán aplicables las reglas del Título III del Libro Segundo de este código.

32 Pfeffer Urquiaga, E.: Código Procesal Penal. Anotado y Concordado, Ed. Jurídica, segunda edición, Santiago, 2006, p. 545.

33 Resolución de la Excma. Corte Suprema recaída en la causa Rol 4954-2008 con fecha 12 de noviembre de 2008.
} 
iniciativa probatoria. Es este último, también, el motivo por el cual se ha asegurado a los intervinientes el derecho a ejercer sus facultades con tiempo y con los medios adecuados. $^{34}$

De tal suerte, que es incuestionable la voluntad legislativa y jurisprudencial que ha extendido al conocimiento y fallo de los recursos procesales la vigencia de los valores propios del juzgamiento de inspiración acusatoria, como el que se aprecia con nitidez en las audiencias de juicio oral.

Así lo sostienen Horvitz y López, quienes, sin embargo, relativizan la inaplicabilidad de las disposiciones comunes a todo procedimiento establecidas en la ley procesal civil al ámbito de los recursos, pues afirman que si bien prevalecen las normas del juicio oral como aquéllas de aplicación supletoria a las generales de los artículos 352 al 361 del Código Procesal Penal, hay asuntos no previstos en ellas que deben resolverse aplicando de modo subsidiario las disposiciones del Código de Procedimiento Civil, como ocurre, por ejemplo, con la orden de no innovar establecida en su artículo $192 .{ }^{35}$

\section{Un sistema de control que no perjudique al recurrente}

El mensaje del Código Procesal Penal al abordar el tratamiento de los recursos procesales expresamente reconoce que el sistema de control de las resoluciones judiciales ha sido diseñado de modo de evitar la concentración de facultades y lograr que cada una de las decisiones de relevancia sea objeto de consideración por más de uno de los órganos del sistema, así como de un debate previo con la mayor transparencia posible.

La pregunta que surge, entonces, es cómo se garantiza normativamente la proscripción de las revisiones de oficio que el Tribunal Superior, bajo una lógica disciplinaria, pueda realizar de las resoluciones del a quo, y cómo se impide, además, que la resolución del recurso perjudique al recurrente o decida más allá o algo distinto de lo pedido por quien reclama.

Y la respuesta la entrega el artículo 360 del Código Procesal Penal, una de las disposiciones relevantes de la parte general de los recursos procesales del Libro III, Título I, de dicho texto legal.

En términos generales, esta norma cautela en sede de impugnación de las resoluciones judiciales, la inspiración acusatoria del actual modelo de juzgamiento penal, desde que persigue garantizar la primacía del contradictorio como presupuesto de la decisión de los asuntos de relevancia en la materia, como también la pasividad e imparcialidad del tribunal ad quem.

\footnotetext{
34 Ibid.

${ }^{35}$ Horvitz Lennon, M. y López Masle, J.: Derecho Procesal... (nota 5), pp. 364 ss.
} 
Echeverría - Límites a la dictación de sentencias penales de reemplazo...

Así, el superior jerárquico es excluido de la iniciativa probatoria y de toda competencia que no le haya sido conferida expresamente por las partes, salvo la posibilidad de anular de oficio la sentencia condenatoria cuando advirtiere la concurrencia de un motivo absoluto de nulidad, con lo cual se garantiza la primacía del debate de partes y la proscripción de decisiones sorpresivas que lesionen garantías tales como el derecho a defensa.

En el libro Reforma procesal penal. Génesis, historia sistematizada y concordancias, consta que el artículo 360 del Código Procesal Penal limitó la competencia de los tribunales superiores para resolver los recursos procesales, prohibiendo expresamente la reforma en perjuicio del recurrente, como también la resolución más allá de lo pedido por el condenado (prohibición para resolver ultra petita) ${ }^{36}$

De hecho, durante la tramitación legislativa, la Comisión de Constitución Legislación y Justicia del Senado dijo que la disposición impide resolver ultra petita, salvo un caso, que quedó referido a la posibilidad de la corte que, conociendo de un recurso de nulidad interpuesto a favor del imputado, puede acogerlo de oficio por un motivo distinto del invocado por el recurrente, siempre que fuere alguno de los motivos absolutos de nulidad. ${ }^{37}$

Sobre los límites al conocimiento y fallo de los recursos procesales, la referida Comisión de la Cámara Alta dijo que el último inciso del nuevo artículo 360 prohíbe la reformatio in peius, en virtud de la cual, si la resolución ha sido objeto de recurso por un solo interviniente, la corte respectiva no podrá reformarla en perjuicio del recurrente. Esta prescripción proviene del artículo 433 del proyecto, que consagraba este principio a propósito del recurso de casación, pero por su trascendencia le pareció (a la Comisión) necesario instaurarlo dentro de las disposiciones generales a todos los recursos. ${ }^{38}$

Lo anterior persigue en buena medida cautelar eso que Luigi Ferrajoli llama la actitud de ecuánime indiferencia del juzgador frente a las pretensiones de quienes litigan en su tribunal, lo que se refleja en la estructura triangular del juicio y que, en sus palabras, se erige en sello de identidad del proceso penal acusatorio ${ }^{39}$. La organización jurídica triádica es indispensable para garantizar la ajenidad del juez frente a los dos intereses contrapuestos -el de la tutela frente a los delitos representado por la acusación y el de la tutela frente a los castigos inmerecidos representado por la defensa- que además corresponden a los dos fines,

\footnotetext{
${ }^{36}$ Maturana M., C. (Coord.): Reforma procesal penal... (nota 9), p. 43.

${ }^{37}$ Comisión de Constitución, Legislación, Justicia y Reglamento del Senado, $2^{\circ}$ Informe., en ibid., p. 47.

$382^{\circ}$ Informe Comisión de Constitución, Legislación, Justicia y Reglamento del Senado; Discusión Particular: art. 394.

${ }^{39}$ Ferrajoli, L.: Derecho y razón, Editorial Trotta, Madrid, Octava Edición, 2006, p. 581.
} 
perfectamente compatibles en abstracto, pero siempre conflictivos en concreto, que, como se ha visto, justifican el derecho penal. ${ }^{40}$

Así las cosas, el desinterés institucional y personal del juzgador frente a las peticiones de los intervinientes ${ }^{41}$ sería el epítome de la imparcialidad del tribunal que, no sólo aparta al juez de la política criminal impulsada por el Legislador y la Administración, sino que erige a la tutela jurisdiccional ${ }^{42}$ en un contrapoder que controla la legalidad de esas actuaciones del Estado, excluyendo la satisfacción de todo apetito personal de la decisión pronunciada, cuestión refrendada en la parte general de los recursos procesales del Título I, Libro Tercero, del Código Procesal Penal, especialmente en lo previsto en los artículos 360 y 361 del texto legal.

\section{2.a. La capacidad del tribunal está determinada por la competencia específica conferida por las partes}

En atención a las razones expuestas es que estamos firmemente convencidos de que la facultad del Tribunal de Nulidad para dictar sentencias de reemplazo no puede fácilmente desentenderse de las peticiones de las partes, como presupuesto de validez de la resolución.

40 Ibid.

41 El artículo 12 del Código Procesal Penal prescribe que para los efectos regulados en este código se considerará intervinientes en el procedimiento al fiscal, al imputado, al defensor, a la víctima y al querellante, desde que realizaren cualquier actuación procesal o desde el momento en que la ley les permitiere ejercer facultades determinadas.

42 En la causa Rol Ingreso Excma. Corte Suprema 4954-2008 el considerando séptimo de la resolución en ella recaída sostiene: "Que en lo que cabe al derecho a defensa, nuestro Código Procesal Penal, señala en el artículo $8^{\circ}$, cuál es el ámbito de la defensa y contempla no sólo el derecho a ser defendido por letrado desde la primera actuación, sino que además, que el imputado tendrá derecho a formular los planteamientos y alegaciones que considere oportunos, así como a intervenir en todas las actuaciones del procedimiento, salvas las excepciones expresamente previstas en este Código.

Esta disposición no es más que una expresión de las garantizadas fundamentales del ser humano, reconocidas en nuestra Constitución Política, en el artículo 19 y primordialmente en su ordinal tercero, que consagra el derecho de toda persona a la defensa jurídica y la obligación de que toda sentencia de un órgano que ejerza jurisdicción esté fundada en un proceso previo, legalmente tramitado.

Tal derecho a defensa parte por el de a ser oído y a intervenir en el juicio, pues es interesado en los resultados del mismo y puede intervenir en la decisión jurisdiccional que podrá afectar algunos de los bienes jurídicos que tiene, entre ellos su libertad personal, su patrimonio. Asimismo, implica el derecho de contradecir las alegaciones del demandante o acusador, a formular sus propias alegaciones destinadas a desvirtuar los cargos formulados en la acusación, a presentar sus pruebas, $\mathrm{y}$ a tener un defensor técnico y jurídico? (Derechos Fundamentales y garantías constitucionales Tomo 2, pág. 300, Humberto Nogueira Alcalá).

Este derecho a contradecir alegaciones y formular las propias, junto a la acreditación de lo reclamado, constituye una expresión de los principios de contradicción y audiencia bilateral, propios de nuestro nuevo sistema procesal penal. La restricción a ese derecho por parte de un tribunal deviene necesariamente en una falta flagrante y grave de su deber de tutela jurisdiccional y una abierta violación al derecho a defensa". 
Echeverría - Límites a la dictación de sentencias penales de reemplazo...

Así, por ejemplo, la capacidad del tribunal es uno de los requisitos de validez de los actos procesales, entre los que se incluye a las sentencias judiciales. $\mathrm{Y}$, por tanto, la capacidad del tribunal equivale a su competencia, definida por el artículo 108 del Código Orgánico de Tribunales como "la facultad que tiene cada juez o tribunal para conocer de los negocios que la ley ha colocado dentro de la esfera de sus atribuciones". ${ }^{3}$

Tal como lo señala el profesor Juan Colombo, la competencia concebida como la capacidad del tribunal para ejercer la jurisdicción en un proceso concreto debe entenderse en el contexto de los principios enunciados por el artículo 7 de la Constitución Política, que expresa: "Los órganos del Estado actúan válidamente previa investidura regular de sus integrantes, dentro de su competencia y en la forma que prescriba la ley".

En ese sentido, el artículo 109 del Código Orgánico de Tribunales establece la denominada "regla de la radicación", en cuya virtud se permite al tribunal ejercer en plenitud su jurisdicción dentro de los ámbitos de competencia absoluta, relativa y específica, que le han sido conferidos para conocer, resolver y hacer cumplir lo juzgado.

Por eso es que la competencia específica del juzgador, concebida como la facultad que tiene el tribunal que radica para resolver el conflicto de intereses sometido a proceso, aparece expresamente circunscrita a las peticiones de los recurrentes, con excepción de aquellos casos en que para beneficiar al condenado se autoriza la revisión de oficio del Tribunal de Nulidad con el propósito de dejar sin efecto condenas fundadas en los motivos absolutos de invalidación del artículo 374 del Código Procesal Penal.

\section{Un caso de sentencia de reemplazo sorpresiva y que causó agravio al condenado}

El pasado 20 de diciembre de 2009 F.A.D.M, mayor de edad, fue condenado en la causa RIT 91-2009 por el Tribunal Oral en lo Penal de Puerto Montt como autor del delito de estupro del artículo $363 \mathrm{~N}^{\circ} 2$ del Código Penal cometido en contra de su hija, circunstancia de parentesco que de acuerdo con la opinión de la mayoría de los jueces de la instancia tornó aplicable la agravante del artículo 13 del mismo texto legal y, por lo tanto, se le impuso una pena de cinco años y un día de presidio mayor en su grado mínimo.

Al comunicarse el veredicto, el defensor penal público que asumió la representación advirtió de inmediato que, atendida la convicción del tribunal, se

\footnotetext{
${ }^{43}$ Colombo Campbell, J.: Los Actos Procesales, Tomo I, Editorial Jurídica de Chile, Santiago, 1999, pp. 299 ss.
} 
hallaba clausurada la posibilidad de pedir el cumplimiento en libertad de la pena, desde que al concurrir una agravante y habiéndose rechazado las atenuantes invocadas por la defensa del acusado, la extensión de pena se ubicaba necesariamente en el tramo de las penas de crímenes normativamente excluidas del régimen de cumplimiento en libertad regulado en la ley 18.216.

De hecho, al comunicarse la sentencia condenatoria, F.A.D.M., quien en ese minuto se encontraba sujeto a medidas cautelares personales no privativas de libertad del artículo 155 del Código Procesal Penal, se reunió con su abogado defensor, oportunidad en que reiteró su inocencia, calificando como errada la decisión del Tribunal Oral en lo Penal de Puerto Montt e instruyó expresamente la presentación de un recurso de nulidad que le permitiera invalidar la condena y someter a un nuevo juicio oral la acusación presentada por el Ministerio Público.

En razón de aquello, la defensa técnica pidió la nulidad del juicio y de la sentencia, desde que se advirtió que la condena infringió el principio del non bis in idem al valorar dos veces la relación de parentesco existente entre F.A.D.M. y su hija, primero para configurar el abuso de la relación de dependencia exigido por el tipo de estupro del artículo $363 \mathrm{~N}^{\circ} 2$ del Código Penal y, luego, por segunda vez, para tener como concurrente la agravante de parentesco prevista en el artículo 13 del mismo texto legal.

En atención a dicho vicio, la defensa penal pública a través del respectivo recurso de nulidad sostuvo que la condena había incurrido en una errónea aplicación del derecho, la cual había influido sustancialmente en lo dispositivo del fallo, y aun cuando el vicio se había originado en el pronunciamiento de la sentencia, dicha circunstancia, de conformidad con el artículo 386 del Código Procesal Penal, no era obstáculo para pedir que se realizara un nuevo juicio oral, lo que en definitiva se solicitó expresamente.

De hecho, al revisar el registro de audio de la vista del recurso de nulidad Rol Corte Puerto Montt N 274-09 consta que, durante la alegación de la defensa, en dos oportunidades se pidió expresamente al tribunal ad quem la nulidad de la sentencia y del juicio oral (pista de audio con registro del alegato de la defensa 0:03 a 0:18 segundos; 11:13 a 11:33 minutos). Esta petición de nulidad de juicio y de nulidad de la sentencia la reiteró nuevamente, y por tercera vez, la defensa durante su alegato de réplica (pista de audio con registro del alegato de réplica de la defensa 02:10 a 02:15 minutos).

\section{3.a. Una victoria pírrica}

El 8 de febrero de 2010 la Corte de Apelaciones de Puerto Montt comunica que acoge el recurso de nulidad presentado por la defensa de F.A.D.M. y coincide en que la aplicación de la agravante de la relación de parentesco infringió la prohibición de doble valoración, desde que la realización del estupro acreditado en la sentencia ya había considerado esa circunstancia. 
Echeverría - Límites a la dictación de sentencias penales de reemplazo...

Sin embargo, para sorpresa del condenado y de su abogado defensor, el Tribunal de Nulidad se desentendió de la petición concreta expuesta en el recurso de nulidad, y sin abrir debate de partes, de oficio, procedió a dictar una sentencia de reemplazo de conformidad con lo dispuesto en el artículo 385 del Código Procesal Penal y rebajó en un día la pena de cinco años y un día originalmente impuesta por el Tribunal Oral en lo Penal de Puerto Montt, que fue invalidada, ordenando su cumplimiento efectivo sin derecho a beneficios de la ley 18.216 y sin haber oído jamás a la defensa sobre los aspectos relevantes para la determinación del castigo, ni tampoco sobre la forma de su ejecución, que, digámoslo, en atención al quántum de pena y a la irreprochable conducta anterior del condenado, debió cumplirse en el medio libre.

Con fecha 15 de febrero de 2010 y luego de enterarse que el recurso de nulidad presentado por su defensa fue acogido, F.A.D.M. por escrito hizo una presentación a la Defensoría Regional, en la que expuso: “¿Qué clase de fallo favorable es éste que injustamente me deja preso y que como una broma de mal gusto me rebaja apenas un día de cárcel (...) Deseo reclamar de la resolución de la Corte de Puerto Montt que injustamente me niega mi derecho a un nuevo juicio oral, a pesar de que reconoció que la sentencia del tribunal oral que me condenó no es válida (...) Según me han informado, nunca se pidió a la Corte de Apelaciones que dictara una nueva condena, se le pidió que anulara el fallo, cosa que hizo y también que se repitiera el juicio y sin dar razones y sin que nadien (sic) lo solicite, ni mi defensor, ni los fiscales, los jueces de la Corte de Puerto Montt dictan una sentencia sin haber estado en el juicio y me condenaron con la misma intensidad que el fallo que anularon (...) Lo anterior lo escribo para constancia de mi deceo (sic) de que se agoten los medios de defensa en mi favor, porque soy inocente de lo que se me acusa y tengo derecho a un nuevo juicio y a estar fuera de la cárcel".

Tras recibir esta petición del condenado, la Defensoría Local de Puerto Montt remitió los antecedentes a la Unidad de Estudios de la Defensoría Regional de Los Lagos para que los evaluara y definiera un curso de acción en defensa de los derechos de F.A.D.M., desde que el artículo 387 del Código Procesal Penal expresamente establece que la resolución que fallare un recurso de nulidad no será susceptible de recurso alguno.

Tras el análisis del caso, se consideró que la privación de libertad impuesta por la Iltma. Corte de Apelaciones de Puerto Montt a F.A.D.M. se fundaba en una sentencia de reemplazo pronunciada con infracción de lo previsto en el artículo 360 del Código Procesal Penal, norma que en la parte general de los recursos procesales resguarda el contradictorio que asegura el derecho a defensa y proscribe la reforma peyorativa pronunciada en perjuicio del recurrente.

Si bien en un primer minuto se evaluó la posibilidad de atacar a través del recurso de queja la referida sentencia de reemplazo pronunciada por la Corte de 
Apelaciones de Puerto Montt, se desestimó esa vía procesal, en atención a los precedentes mayoritarios de la segunda sala penal de la Corte Suprema que salvo excepciones ha rechazado in limine esa vía extraordinaria de impugnación. ${ }^{44}$

\section{3.b. Fundamentos de la acción de amparo constitucional}

En definitiva se accionó de amparo a favor de F.A.D.M. para que una sala integrada por ministros no inhabilitados de la Iltma. Corte de Apelaciones de Puerto Montt conociera de este remedio constitucional.

Su fundamento se hizo descansar en el hecho que la pena de cinco años de privación de libertad fue impuesta al condenado con infracción de las leyes que reglan el procedimiento y por un tribunal como la Corte de Apelaciones, que, en el caso concreto, carecía de competencia para pronunciar una condena que resultó enteramente sorpresiva para el justiciable y su defensa técnica.

Además se argumentó que la Iltma. Corte de Apelaciones de Puerto Montt no abrió debate sobre la posibilidad de acceder a beneficios de la ley 18.216 legalmente procedentes en atención a la pena impuesta, razón por la cual se resolvió de oficio este punto que en definitiva lesionó la libertad del amparado, sin haber oído a las partes.

Por último se sostuvo que la resolución recaída en el recurso de nulidad interpuesto en contra de la sentencia condenatoria no dice ni explica por qué razón la Iltma. Corte de Apelaciones de Puerto Montt se apartó de la competencia que le fuera concedida por el recurrente, ni tampoco fundamentó las motivaciones que tuvo en cuenta para extender los efectos de la nulidad de la sentencia condenatoria más allá de los límites de lo expresamente solicitado en el recurso de nulidad presentado a favor de F.A.D.M., y que en definitiva acogió, aunque con efectos perjudiciales para las pretensiones del amparado al dictar una sentencia de reemplazo cuya extensión y forma de cumplimiento no se le permitió discutir.

\section{3.c. La sentencia de reemplazo como prerrogativa absoluta de las cortes}

La Corte de Apelaciones de Puerto Montt rechazó la acción de amparo sobre la base del siguiente argumento principal: "Que, teniendo presente que la acción cautelar de amparo se encuentra destinada para el caso de que un individuo sea detenido o preso con infracción a la Constitución y las leyes, estos sentenciadores

\footnotetext{
44 Ver causas Rol Excma. Corte Suprema Rol No 4913-08; 5830-08 y 4370-08, entre otras. En lo fundamental, la opinión mayoritaria sostiene que, de conformidad con lo dispuesto en el artículo 387 del Código Procesal Penal, la resolución que falle un recurso de nulidad no será susceptible de recurso alguno.

Y visto además, lo dispuesto en los artículos 545 y 549 del Código Orgánico de Tribunales, se declara inadmisible el recurso de queja interpuesto en lo principal de fojas 2.
} 
Echeverría - Límites a la dictación de sentencias penales de reemplazo...

concluyen que no ha sido el caso del amparado F.A.D.M. quien por el contrario, fue privado de libertad en cumplimiento de una sentencia pronunciada por tribunal competente que conoció de un recurso de nulidad promovido por su propia defensa, prestando acogida al citado recurso respecto de una de las causales de nulidad invocadas, y que haciendo uso de la facultad que le concede el artículo 385 del Código Procesal Penal, dictó sentencia de remplazo mediante la que impuso al imputado una pena de cinco años de presidio menor en su grado máximo, de conformidad con lo dispuesto en el artículo 68 del Código Penal, aplicando “...la pena condigna al delito teniendo en consideración las circunstancias de comisión y la condición de vulnerabilidad de la víctima, atendida su minoría de edad, en un marco de dependencia emocional y económica respecto del hechor, además de las consecuencias ulteriores que tanto en lo material como en su personalidad ha debido producir la conducta ilícita del enjuiciado", y no se concede al sentenciado el beneficio de la libertad vigilada por carecer del informe a que se refiere la letra c) del artículo 15 de la Ley 18.216".

Si bien la Corte de Apelaciones de Puerto Montt nunca abrió debate para que las partes pudieran debatir la extensión de la pena y su forma de cumplimiento, razón por la cual la defensa no pudo aportar los informes y antecedentes que recomendaban la libertad de F.A.D.M., la resolución que rechazó en primera instancia la acción de amparo constitucional impetrada en su favor fue confirmada por la Excma. Corte Suprema, que escuetamente sostuvo: "Que el artículo 385 del Código Procesal Penal entrega una facultad a los jueces para dictar sentencia de reemplazo en los casos que aquella misma disposición señala, prerrogativa que fue utilizada por los recurridos para proceder en la forma que se hizo, en un caso expresamente contemplado en ella, de donde se sigue que no existió la ilegalidad ni arbitrariedad que se reclama". ${ }^{46}$

\section{Sentencia de reemplazo: facultad legal de oficio y garantías fundamentales}

A este propósito surge la pregunta: ¿En el caso de que concurran las hipótesis del artículo 385 del CPP, puede la defensa solicitar la nulidad de la sentencia y del juicio oral y renunciar a la posibilidad de una sentencia reemplazo o el tribunal ad quem está obligado a dictar sentencia de reemplazo a pesar de la solicitud de nulidad del juicio planteada por la defensa?

Cristián Arias sostiene que en las hipótesis del artículo 385 del Código Procesal Penal resulta facultativo para el tribunal dictar la sentencia de reemplazo,

\footnotetext{
45 Considerando séptimo de la resolución recaída con fecha 26 de febrero de 2010 en recurso de amparo ingresado a la secretaría de la Iltma. Corte de Apelaciones de Puerto Montt bajo el Rol N ${ }^{\circ}$ 28-2010.

${ }^{46}$ Resolución pronunciada el 11 de marzo de 2010 por la Excma. Corte Suprema en la causal Rol $\mathrm{N}^{\circ}$ 1756-10.
} 
pudiendo siempre optar por el reenvío para la realización de un nuevo juicio oral, según resulta de considerar, con la suficiente importancia que tiene el empleo del vocablo "podrá" escogido por el legislador. ${ }^{47}$

Así, para este autor, la facultad para dictar sentencia de reemplazo se encuentra establecida sólo en favor del imputado, como se puede concluir de las hipótesis que la hacen procedente, todas las cuales se refieren a una sentencia de juicio que ha resultado gravosa para éste. "El legislador es capaz de sacrificar el concepto de instancia -conocimiento cabal y sin mediación tanto de los hechos como del derecho- sólo en la medida que ello no perjudique al imputado y, por el contrario, a todas luces lo beneficie". ${ }^{48}$

\section{4.a. La interpretación a favor de la economía procesal.}

El profesor Cristián Maturana Míquel, en cambio, sobre la base de consideraciones de economía procesal, sostiene que la dictación de una sentencia de reemplazo por parte del Tribunal de Nulidad lejos de ser una facultad como lo establece el artículo 385 del Código Procesal Penal es un deber irrenunciable de dicho tribunal, que no limita en las peticiones concretas formuladas por el recurrente en su recurso de nulidad.

"En este caso, aun cuando la ley utilice una expresión de carácter facultativo como es 'podrá', nos encontramos ante una situación de carácter imperativa, por lo que de acogerse el recurso de nulidad por alguno de dichos motivos deberá el tribunal ad quem dictar no sólo la sentencia de nulidad, sino también en forma separada la sentencia de reemplazo para fallar el fondo del asunto, aplicando correctamente la ley en caso de acogerse el recurso de nulidad por alguno de los motivos establecidos ${ }^{49}$ en el artículo 385 del Código Procesal Penal (...) En este caso la Corte debe actuar de ese modo, porque el vicio no dice relación con actos del juicio oral y no es necesario el establecimiento de hechos distintos a los contenidos en la sentencia impugnada para dar una correcta aplicación al derecho. ${ }^{50}$

Agrega el referido autor que entiende que ésta es la correcta interpretación para conducirnos a un proceso que no incurra en dilaciones indebidas y que permita brindar a la población la pronta y cumplida Administración de Justicia a

\footnotetext{
47 Arias Vicencio, C.: “El recurso de queja en el nuevo procedimiento penal”, en Revista de Estudios de la Justicia (REJ), $\mathrm{N}^{\circ}$ 1, año 2002, Facultad de Derecho de la Universidad de Chile, Santiago, 2002, p. 162.

48 Ibid.

49 Maturana Míquel, C.: "Los Recursos”, Escuela de Derecho Universidad de Chile, Santiago, 2008, pp. 297 ss.

50 Ibid.
} 
Echeverría - Límites a la dictación de sentencias penales de reemplazo...

que se refiere el artículo 77 de nuestra Carta Fundamental, las que deben ser respetadas para que nos encontremos ante un debido proceso. ${ }^{51}$

\section{4.b. Eficiencia no es sólo celeridad y ahorro de recursos, sino también oportunidad de defenderse}

Sin embargo, nos permitimos disentir de la conclusión a la que arriba el profesor Maturana Míquel cuando afirma que en las hipótesis del artículo 385 del Código Procesal Penal el tribunal de nulidad debe imperativamente dictar sentencia de reemplazo.

Lo anterior, por cuanto esta interpretación descansa en dos premisas discutibles. Así, el contradictorio de partes en el actual proceso penal está lejos de concluir con la fijación de los hechos comunicados en el veredicto condenatorio, desde que la determinación judicial de la pena debe ser precedida por el debate de partes, como lo reconoce expresamente el artículo 343 del Código Procesal Penal, y los fines de economía procesal invocados como fundamento legitimador de la dictación de oficio de la sentencia de reemplazo deberían ceder frente al deber de respeto de las garantías de inviolabilidad de la defensa y debido proceso.

De hecho, el artículo $7^{\circ}$ del Código Procesal Penal establece que las facultades, derechos y garantías que la Constitución Política de la República, este Código y otras leyes reconocen al imputado, podrán hacerse valer por la persona a quien se atribuyere participación en un hecho punible desde la primera actuación del procedimiento dirigido en su contra y hasta la completa ejecución de la sentencia.

\section{4.c. Acogida la nulidad, ¿ sus efectos están determinados por la ley y no por el petitorio de partes?}

Entonces la pregunta, de cara al respeto al debate previo de partes y a las garantías del debido proceso, es cómo y cuándo puede el Tribunal de Nulidad dictar una sentencia de reemplazo sin atropellar estos presupuestos.

Según el profesor Raúl Tavolari, citado por Rodrigo Cerda San Martín ${ }^{52}$, la competencia de la corte para analizar la procedencia del recurso de nulidad se encuentra determinada en primer lugar por las causales señaladas en la ley y, adicionalmente, por las peticiones concretas del recurso.

No obstante lo señalado, Rodrigo Cerda San Martín sostiene que las limitaciones que el recurrente impone a la corte en el conocimiento del recurso, se refieren a las causales de nulidad, mas no a la pretensión de invalidación, pues los

\footnotetext{
${ }^{51}$ Ibid.

${ }^{52}$ Cerda San Martín, R.: Etapa intermedia. Juicio oral y recursos, Ed. Librotecnia, Santiago, 2003, pp. 299 ss.
} 
pasos a seguir una vez decidida la nulidad están determinados por la ley, como se aprecia de la lectura de los artículos 385 y 386 del Código Procesal Penal. ${ }^{53}$

Si se aceptara que las peticiones concretas del recurrente no se extienden a los efectos derivados de la anulación establecidos en la ley, entonces la pregunta es inevitable: ¿Cómo se interpreta y aplica la facultad que el artículo 385 confiere a las cortes para dictar una sentencia de reemplazo al margen de la realización de un nuevo juicio, sin que el ejercicio de ese poder de decisión vulnere la garantía que asegura el derecho a defensa, al debate previo de partes y el debido proceso hasta la completa ejecución del fallo?

Una respuesta la entrega el profesor Rodrigo Cerda San Martín, quien escribe que la sentencia de reemplazo es excepcional, ya que sólo opera cuando la causal que se acoge dice relación con la aplicación del derecho; discrecional, porque resulta facultativo para el tribunal dictarla; y unilateral, porque sólo opera en beneficio del acusado. Ello es así, pues de otro modo se podría afectar indirectamente el derecho al juicio, ya que se estaría resolviendo el asunto fuera de instancia, fuera de la única instancia que se contempla y que es ante el tribunal del juicio. Esta decisión fuera de instancia no le agrada al legislador, a tal punto, que no considera obstáculo para repetir el juicio oral el hecho de que el vicio o defecto se haya cometido en el pronunciamiento mismo de la sentencia. ${ }^{54}$

Coincide el profesor Juan Carlos Marín, quien plantea que en las tres hipótesis previstas en el artículo 385 del Código Procesal Penal, la sentencia de reemplazo siempre debiera favorecer al condenado-recurrente, ya sea porque se va a dictar una sentencia absolutoria o una condenatoria con una pena inferior a la que se estableció en la sentencia del tribunal de juicio oral en lo penal ${ }^{55}$.

\section{4.d. Iura novit curia y contradictorio como presupuesto de validez del fallo}

Ahora bien, ¿Puede el Tribunal de Nulidad per se dictar de oficio una sentencia de reemplazo que sea inferior a la que fue invalidada en razón de haberse acogido el respectivo recurso o aun en estas hipótesis debe respetar el contradictorio de partes como presupuesto básico del ejercicio del derecho a defensa?

Si bien de acuerdo con el principio iura novit curia, el juzgador sería soberano para calificar jurídicamente los hechos de la imputación que se han tenido por probados, como también para determinar la pena, el Código Procesal Penal exige en términos imperativos que ese tipo de decisiones hayan sido precedidas siempre del respectivo debate de partes, tal como lo prescriben los

\footnotetext{
${ }^{53} \mathrm{Ibid}$.

54 Ibid.

${ }^{55}$ Marín G., J: “El recurso de nulidad..." (nota 4), p. 55.
} 
Echeverría - Límites a la dictación de sentencias penales de reemplazo...

artículos 341 y 343 del referido texto legal, que deben entenderse como garantía de la inviolabilidad de la defensa.

En materia penal, Carlos Del Río Ferretti reconoce al derecho a defensa y al contradictorio de los intervinientes como un límite a los poderes jurisdiccionales de calificación jurídica de oficio de los hechos imputados y probados, desde que siempre la nueva tesis del tribunal debe someterse al debate previo de partes, prescrito por el artículo 341 del Código Procesal Penal.

Incluso, postula que el acusado y su representación técnica podrían solicitar la suspensión de la audiencia de juicio oral de acuerdo con el 283 del mismo texto legal, para preparar debidamente la defensa, o bien, ofrecer prueba nueva de conformidad con lo prevenido en el artículo 336 del Código Procesal Penal. ${ }^{56}$

En materia de determinación de penas, Del Río Ferretti también reconoce el libre ejercicio de la facultad judicial de determinación de la consecuencia penal, incluso más allá del petitum de la acusación, aunque también subordinada a la doble restricción de especial motivación de la identificación concreta del castigo y de respeto al debate previo de partes consagrado para estos efectos por el artículo 343 del Código Procesal Penal, que, además, expresamente reconoce que en la individualización de la sanción pueden ser relevantes circunstancias y factores distintos al hecho fijado por los jueces en su veredicto. ${ }^{57}$

\section{4.e. La forma de cumplimiento de la pena debe ser debatida por la defensa, porque integra la sentencia definitiva}

Entre los aspectos ajenos a la acusación y, a la vez, trascendentes a la hora de individualizar judicialmente la pena, resultan de especial relevancia aquellos referidos al eventual cumplimiento alternativo de las privaciones o restricciones de libertad, respecto de lo cual ha llamado la atención el abogado Ignacio Barrientos Pardo, quien ha escrito que el pronunciamiento sobre las medidas alternativas al encierro del condenado integran la sentencia definitiva de conformidad con lo establecido en el artículo 348 del Código Procesal Penal, razón por la cual ha postulado fundadamente el derecho de la defensa a impugnar a través del recurso de nulidad la denegación de dichos beneficios al término del procedimiento ordinario o simplificado. ${ }^{58}$

Es evidente que una sentencia de reemplazo pronunciada por el Tribunal de Nulidad al margen de las peticiones del recurrente se erige en una seria amenaza

\footnotetext{
56Del Rio Ferretti, C.: Los poderes de decisión del juez.penal, Editorial Jurídica de Chile, Santiago, 2009, pp. 103 ss.

57 Ibid, p. 291.

${ }^{58}$ Barrientos Pardo, I.: "Recurso efectivo contra la sentencia que no concede beneficios de la ley N 18.216", en Revista de Estudios de la Justicia (REJ), N¹1, Santiago, 2009, pp. 265 - 318.
} 
al derecho de defensa, desde que este aspecto referido a la forma de cumplimiento de la pena y a la mayor o menor afectación de la libertad del condenado se decidiría de oficio, al margen del contradictorio y sin posibilidad de acompañar los antecedentes relevantes para su resolución.

Algo similar ocurre con la determinación de las sanciones aplicables al condenado por hechos cometidos durante su minoría de edad de acuerdo con la ley 20.084 sobre responsabilidad penal adolescente (LRPA). Sabido es que, en esta materia, tanto o más importante que la extensión del castigo derivado del injusto culpable que ha tenido por acreditado el órgano jurisdiccional es realmente la determinación de la naturaleza de la sanción uno de los asuntos que mayor discusión en juicio suscita y que permanentemente desafía la verdadera especialización de los operadores jurídicos, atendida la diversificación de reacciones posibles y los expresos propósitos de reintegración social asignados a este régimen sancionatorio especial.

Y esta disputa se ventila precisamente después de fijados los hechos por el tribunal y luego de comunicado el veredicto condenatorio, en una audiencia posterior a la del juzgamiento. El artículo 40 de la LRPA establece que la audiencia de determinación de pena del artículo 343 del Código Procesal Penal se realizará de forma obligatoria en todos los casos de sentencia condenatoria. Con ello se despeja toda duda sobre el momento de discusión de los criterios y reglas relevantes para la determinación de la extensión y naturaleza de la sanción. Es en esa oportunidad que los intervinientes tienen la posibilidad, y deber, de esgrimir todos los argumentos conducentes a individualizar la pena aplicable. ${ }^{59}$

\section{4.f. La defensa tiene derecho a expresarse hasta la completa ejecución del fallo}

La determinación de la pena es por regla general una facultad judicial que a nuestro entender se debe ejercer en el actual sistema procesal penal con total y absoluto respeto a la garantía que asegura el derecho a defensa hasta la completa ejecución del fallo. ${ }^{60}$ Más aun en materia de responsabilidad de los adolescentes por infracciones a la ley penal, en que autores como Gonzalo Medina Schulz expresamente han dicho que la defensa, a través del recurso de nulidad, cuenta con dos causales de impugnación de la condena impuesta en procedimiento ordinario y simplificado: (i) el control por falta de fundamentación de la sentencia y (ii) por vulneración del derecho. "Ambas, no son sino aspectos sucesivos de la necesaria expresión de racionalidad de la sanción aplicada. La infracción de derecho no puede ser revisada, sino en la medida en que las argumentaciones que subyacen han sido expresadas. Pero la sola expresión de las argumentaciones es condición

\footnotetext{
59 Medina Schulz, G.: "Sobre la determinación de pena y el recurso de nulidad en la ley 20.084 sobre responsabilidad penal adolescente", en Revista de Estudios de la Justicia (REJ), N ${ }^{\circ} 11$, Santiago, 2009 , p. 215.

${ }^{60}$ Art $19 \mathrm{~N}^{\circ} 3$ de la Constitución Política del Estado y artículos $7^{\circ}$ y $8^{\circ}$ del Código Procesal Penal.
} 
Echeverría - Límites a la dictación de sentencias penales de reemplazo...

necesaria pero no suficiente de la racionalidad en la determinación de la pena. El juez no está dotado de una facultad incontrolable en la materia, sino que las discordancias fundadas con el razonamiento judicial son suficientes para la revisión de la sentencia". ${ }^{11}$

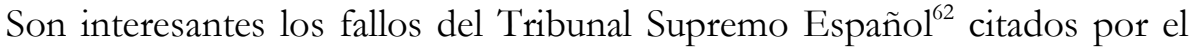
profesor Del Río Ferretti ${ }^{63}$, donde se ha entendido, por ejemplo, que la sentencia que de oficio impone una pena accesoria meramente facultativa infringe el principio acusatorio que proscribe la indefensión, desde que su aplicación sería válida sólo cuando se ha permitido a la defensa controvertir su procedencia, porque esta garantía prevalece la pura legalidad de la sanción.

Así, entonces, una interpretación conforme al debido proceso de la facultad concedida al Tribunal de Nulidad por el artículo 385 del Código Procesal Penal nos permite concluir que la sentencia de reemplazo sólo puede dictarse en los casos y circunstancias expresamente previstos en la referida norma, siempre subordinada a la expresa petición de la defensa del recurrente, a menos que los jueces consideraren que hay aspectos de la determinación de la pena o de su naturaleza que no están en condiciones de apreciar por no haber presenciado la audiencia de juicio oral, en cuyo caso podrían excepcionalmente desentenderse de la solicitud del condenado, y en el evento de acoger el recurso de nulidad, omitir el pronunciamiento de la sentencia de reemplazo para dictar una resolución de reenvío que permita a un tribunal no inhabilitado conocer en un nuevo juicio oral de la acusación, lo que desde nuestra perspectiva no causa agravio al recurrente porque preserva incólume el debido proceso y el derecho a defensa técnica del justiciable en un marco de respeto a la prohibición de reformatio in peius.

Por el contrario, entender que la expresión "podrá" utilizada por el artículo 385 del Código Procesal Penal faculta a las cortes para dictar sentencias de reemplazo sin previa y expresa petición del recurrente, importa en el hecho permitir que se determine la extensión y naturaleza de la pena al margen del debate de partes $y$, por lo tanto, con infracción a la garantía que asegura la vigencia del derecho a defensa hasta la completa ejecución de la sentencia.

\footnotetext{
${ }^{61}$ Medina Schulz, G.: "Sobre la determinación..” (nota 59), p. 234.

${ }^{62}$ Un ejemplo nos lo da la STS de 30 de enero de 1995 que estimó que infringía el principio acusatorio una sentencia de la AP que le impuso al acusado una pena accesoria de comiso (en el CPe de 1995, el comiso es tratado como consecuencia accesoria). El TS estableció que si quería imponer la pena (consecuencia accesoria) debió haberse sometido a debate sin que bastara la petición genérica de penas accesorias. Establece que si se impone una pena accesoria en la sentencia condenatoria no pedida por las partes acusadoras se infringe el principio acusatorio y la congruencia, según lo señala en el fundamento de derecho tercero de la sentencia. En el mismo sentido sentencia de 12 de noviembre de 1992 (BDA, m.RJ 1992/9662); sentencia de 8 de mayo de 1993 (BDA, m. RJ 1993/3769), todas citadas por Del Río Ferretti, C.: Los poderes de decisión... (nota 56), p. 293.

${ }^{63}$ Del Río Ferretti, C.: Los poderes de decisión... (nota 56), pp. 292 - 299.
} 
REJ - Revista de Estudios de la Justicia - No 13 - Año 2010

\section{BIBLIOGRAFÍA}

* ARIAS Vicencio, Cristián: "El recurso de queja en el nuevo procedimiento penal", en Revista de Estudios de la Justicia (REJ), $\mathrm{N}^{\circ}$ 1, Facultad de Derecho de la Universidad de Chile, Santiago, 2002.

* BARRIENTOS Pardo, Ignacio: "Recurso efectivo contra la sentencia que no concede beneficios de la ley N 18.216", en Revista de Estudios de la Justicia (REJ), N 11, Santiago, 2009.

* BORDALÍ Salamanca, Andrés: "El derecho fundamental a un tribunal independiente e imparcial en el ordenamiento jurídico chileno", en Revista de Derecho de la Pontificia Universidad Católica de Valparaíso, XXXIII, Valparaíso, $2^{\circ}$ Semestre de 2009.

* CERDA San Martín, Rodrigo: Etapa intermedia. Juicio oral y recursos, Ed. Librotecnia, Santiago, 2003.

* CORTEZ Matcovich, Gonzalo: El recurso de nulidad, doctrina y jurisprudencia, Editorial Lexis Nexis, Santiago, 2006.

* DEL RÍO Ferretti, Carlos: Los poderes de decisión del juez. penal, Editorial Jurídica de Chile, Santiago, 2009.

* ECHEVERRÍA Ramírez, Germán: "Imparcialidad del Tribunal Oral en lo Penal: tras la conquista de la garantía", en Revista de Derecho Universidad de Austral de Chile, volumen XXIII-N ${ }^{\circ}$ 1, Valdivia, 2010.

* FERRAJOLI, Luigi: Derecho y razón, Editorial Trotta, Madrid, octava edición, 2006.

* HORVITZ Lennon, María Inés y LÓPEZ Masle, Julián: Derecho Procesal Penal Chileno, Tomo I, Editorial Jurídica de Chile, Santiago, 2002.

* MARÍN González, Juan Carlos: "El recurso de nulidad en el Código Procesal Penal: el reenvío y la sentencia de reemplazo", en Informes en Derecho, $N^{\circ} 6$, Ed. Centro de Documentación de la Defensoría Penal Pública, Santiago, 2009.

* MATURANA Míquel, Cristián (Coord.): Reforma Procesal Penal. Génesis, historia sistematizada y concordancias, T. III, Editorial Jurídica de Chile, Santiago, 2003.

Los Recursos, Escuela de Derecho Universidad de Chile, Santiago, 2008.

* MEDINA Schulz, Gonzalo: "Sobre la determinación de pena y el recurso de nulidad en la ley 20.084 sobre responsabilidad penal adolescente", en Revista de Estudios de la Justicia (REJ), $\mathrm{N}^{\circ} 11$, Santiago, 2009.

* PFEFFER Urquiaga, Emilio: Código Procesal Penal. Anotado y Concordado, $2^{\circ}$ edición, Editorial Jurídica de Chile, Santiago, 2006.

* RIEGO, Cristián y DUCE, Mauricio: Proceso Penal, Editorial Jurídica de Chile, Santiago, 2008.

* TAVOLARI, Raúl: Instituciones del nuevo proceso penal, Editorial Jurídica de Chile, Santiago, 2005.

* VALENZUELA Cori, Rodrigo: Conflicto y Humanidades. Un Ensayo sobre Argumentación Jurídica, $1^{\circ}$ edición Editorial Jurídica de Chile, Santiago, octubre 2004. 